\title{
Is Islam with or against Tourism? Halal Tourism Perception; Definition and Requirements
}

\section{Maryam Taha Mannaa}

Assistant Professor, History and Islamic Civilization Department, College of Arts, Humanities and Social Sciences, University of Sharjah, Sharjah, UAE

Lecturer, Tourism Studies Department, Faculty of Tourism and Hotels, Alexandria University, Alexandria, Egypt

\section{Abstract:}

Although, Halal tourism is generally linked in research with travel conducted by Muslims, this is the first research to verify the religious judgment of tourism in Islam as per Quran and Sunnah, being the main resources for Islamic shariah (law).

Travel and hospitality projects are facing a problem which is the lack of standardization in the Halal tourism industry. The term Halal tourism carries a lot of interpretations and confusion in research. After the remarkable increase in the number of Muslim travellers, there is an urgent need for a global agreement on what constitutes Halal tourism.

This paper helps to define clearly what is considered Halal and to set some rules and regulations for reference. This paper is of a conceptual base with a goal of building a clearer theory of Halal Tourism and its requirements. The study depends on secondary information. And ends up with some recommendations of practical use for tourism suppliers.

Key words: Halal Tourism; Religious Tourism; Muslims; Shari'ah.

\section{Introduction}

It is anticipated that the Muslim population will reach $26.5 \%$ of the world's population by 2030 (MasterCard and CrescentRating, 2016). The majority of the Muslim population are from some of the fastest developing economies such as Indonesia, Malaysia, Turkey and the Gulf countries. Muslims are now considered a significant consumer market for the whole world.

For Muslims, faith is substantially shaping their purchasing choices on daily basis. They purchase the products and services that satisfy their faith based limitations. This has been reflected in business over the last decade by the vast growth of Halal food, Islamic banking and Halal tourism.

The Muslim travel segment is one of the fastest growing markets in the international tourism industry. In 2015, it was projected that there were 117 million Muslim international travellers. By 2020, the number is expected to reach 168 million while the travel expenditure by Muslim travellers is anticipated to surpass USD 200 billion (MasterCard and CrescentRating, 2016; Pew Resource Center, 2011).

From demographic view, the typical Muslim consumer is now younger, well-educated with more disposable income to spend on travel (MasterCard and CrescentRating, 2016). This means that travel and hospitality suppliers need to understand the powerful potential of this segment and its unique needs relating to faith if they really aiming after it.

\section{Muslim Market}

While the total world populace is anticipated to grow by $35 \%$ in the coming decades, the number of Muslims is expected to rise by $73 \%$ from 1.6 billion in 2010 to 2.8 billion in 2050. In 2010, Muslims made up 23.2\% of the worldwide populace and it is expected to reach $26 \%$ by 2030 (MasterCard and CrescenRating, 2015).

Pew Research Center report anticipates that Muslims will grow more than twice as fast as the overall world populace between 2010 and 2050 and, in the second half of this century, will probably outperform Christians as the world's largest religious group. After four decades, they are expected to constitute around three-in-ten of the world's folks (29.7\%), see Figure 1. 


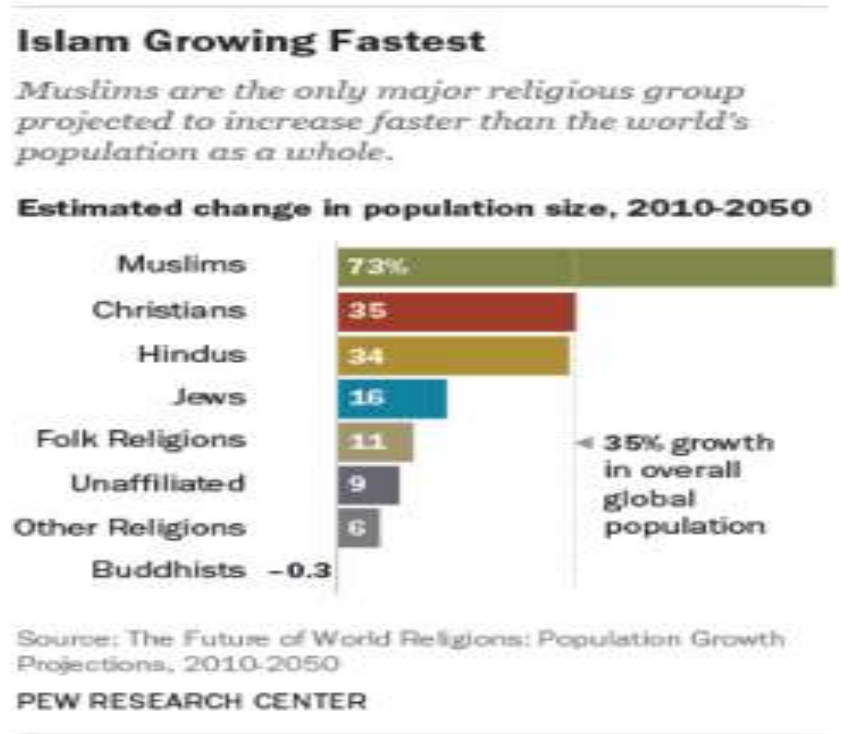

Figure (1) Estimated change in religious groups' size

Source: Pew Research Center.

By 2030, Europe's Muslim population is expected to increase from $6 \%$ to $8 \%$. With the vast migration movements of Muslims from Syria and other Arab countries suffering from war and political instability, the ratio of Muslims in Europe might dramatically surpass 8\%; 60\% of Muslims originate from Asia and one fifth from the Middle East and North Africa. Also, 400-600 million Muslims live as minorities in other areas: 38.1 million in Europe, 8 million in the USA and 1 million in Canada. According to the Office for National Statistics, the Muslim population in the UK increased from 1.55 million in 2001 to 2.7 million in 2011(Stephenson, 2014)

Muslim consumers are one of the fastest growing business fragments on the planet. Statistical surveying conducted in mid-2010, recognized that one essential target segment for worldwide businesses is the 'under 30 s' segment, speaking of $42 \%$ of the Muslim populace (Stephenson, 2014).

\section{Muslim Tourists:}

Globally Muslim tourists represent a major niche market. The worldwide income from Muslim tourists in 2011 was evaluated at \$USA 126 billion, constituting 12.3 per cent of the total worldwide outbound tourism income as estimated by UNWTO. These numbers exclude religious journeys of Haj and Umrah (Dinar Standard and Crescentrating, LLC, 2012).

While European and North American consumers account for $60 \%$ of worldwide tourism in 2010, the most notable trend over the last decade has been the growing contribution of travellers from Asia (which includes MENA based tourists), rising from a 23\% share in 2000 to $30 \%$ in 2010. Growth of incomes in both emerging and developed Asian economies is behind this upswing. While Asia region in aggregate has shown the greatest growth in tourist exports, among the top 20 countries that have had the greatest growth in international tourism expenditure between 2005-2010, 25\% of that growth in expenditure was from OIC (Organization of Islamic Cooperation) member countries with Muslim majority populations (Dinar Standard and Crescentrating, LLC, 2012). One study has estimated the expenditure of about 15,000 tourists from the Middle East as \$78 million on the Gold Coast, Queensland, Australia each year, compared with114,000 Chinese tourists spending $\$ 67$ million. This makes the Middle East tourists the prime spending group per capita on the Gold Coast (Abodeeb et al., 2015).

Of the total 1.62 billion global Muslim populations in 2011, $78 \%$ reside in the 57 OIC (Organization of Islamic Cooperation) mostly Muslim majority countries. Of the total estimated Muslim tourism expenditure 
in 2011, 82\% came from the OIC member countries (\$102.9 billion) (Dinar Standard and Crescentrating, LLC, 2012).

\section{Muslim Tourism Market Potentials}

The majority of Muslim markets are now fast developing economies, with higher than international average population growth rates, and a younger demographic. The expenditure of Muslim tourists is expected to grow at a higher rate than the global expected average. While the global expected average growth rate is $3.8 \%$ through 2012-2020, the Muslim tourist average growth rate is expected to reach $4.79 \%$ per year during the same period. According to a report by Thomson Reuters and Dinar Standard (2013) Halal tourism was worth US\$ 137 billion in 2013 and expected to reach US\$ 181 billion by 2018. By 2020, it is anticipated that the total Muslim tourists' expenditure to exceed USD 200 billion (MasterCard and CrescentRating, 2016).

UNWTO forecasts that there will be 69 million outbound tourist arrivals generated from the Middle East in 2020 representing an average annual growth rate of 6.7\% over the period 1995-2020 which is above the global average. A report cited by UNWTO showed that the Arab Gulf countries spend $\$ 20$ billion on vacations every year, led by Saudi tourists whose expenditure reaches $\$ 8.5$ billion. (UNWTO, 2008).

With an aim to share the profits of this huge segment of Halal tourism, hoteliers in many Muslim and nonMuslim countries have started to offer customized offers in accordance with the Islamic principles.

\section{Islam perception for travel}

The Quran often recommends visiting other places for cultural encounters, to gain knowledge, to associate with other Muslims, to spread God's word, and to enjoy and appreciate his creations (Scott and Jafari, 2011).

There are many verses in the Holy Quran that encourage travelling around the world and gathering information about different places and people. In the holy Quran not only does Allah (the most common name for God in Islam) regard travelling as legitimate but rather recommended for several advantages.

Generally, travelling-related verses can be classified into four groups:

The first Group is the verses which criticize those who abandon travelling. These verses, mostly, refer to unbelievers and advise them to travel through the earth to see the doom of those disbelievers who lived in the past and who were even stronger than them and how God destroyed them because of their sins. These verses clearly indicate that Islam favors travelling to gain experience and to learn from history as the past is a guide for the future. Such indication has been repeated in many verses of the holy Quran such as: Al-Imran 3:137,Al-An'am 6:11, Al-Nahl 16:36, An-Naml 27:69, Al-Ankabut 29:20, Ar-Rum 30:42, Fatir 35:44, Yusuf 12:109, Ghafir 40:82, and Muhammad 47:10.

Some of these verses not only encourage travelling but rather order people to do so as a duty through the use of the imperative verb. The phrase "go travel around the world" which commands people to travel has been repeated 6 times in the Holy Quran, and it has been referred to in the following verses: Al-Imran 3:137, AlAn'am 6:11, Al-Nahl 16-36, An-Naml 27:69, Ar-Rum 30:42.

The second group of travelling verses in Quran asks people to travel to gain wisdom and to get their minds and heart open. The verse 46 in Suraht Al Hajj says: "Do they not travel through the land so that their hearts may learn wisdom and their ears may learn to hear? Verily, it's not the eyes that are blind, but the hearts which are in their breasts that grow blind."

The third group of verses order people to travel over the earth to appreciate the creation of the God. In Suraht Al-Ankabut (the spider) 29:20 God says "Travel through the earth and see how Allah did originate creation and so Allah will produce a later creation. Verily, Allah has power over all things." In this verse people are ordered to travel through earth to appreciate the creation of God and to try to understand how Allah started it and how it will be easier for him to recreate it after death on the afterlife. 
The last type of travel recommended and sometimes obliged travelling for Hajj and Umrah. Hajj is the religious journey to Makkah and is the fifth pillar of Islam; it is required once in lifetime for each Muslim if capable physically and financially. Umrah is also a religious journey to Makkah, however not compulsory rather recommended.

Moreover, Prophet Mohammed encouraged Muslims to travel on many occasions and indicated travellers to be closer to God and their requests and wishes from God are more responded to while travelling. Moreover, the religious duties for travellers are less as traveller can pray shorter prayers, can postpone prayers and can choose not to fast in the holy month of Ramadan and postpone his/her fasting till after he/she is back home.

\section{Muslims' travel patterns}

Since the early days of Islamic history when the Islamic empire covered massive geographical areas of Asia, Africa and even some parts of Europe, Muslims (and non-Muslims) got the chance of travel across these three continents safely and without any restrains such as passports, borders or security inquiries. History is full of many examples for famous Muslim travellers such as Ibn Battuta who was, and still is, one of the most famous travellers in history. Other examples include Abdellatif El Baghdadi, Ibn Wahb Al-Qorashi, Osama Bin Monqid, El Harawi As-Sa'ih, and others (El-Gohary, 2016).

Muslims practice different patterns of travel, some of them are for religious purposes, others are not.

\section{Travel for Religious Purposes}

Muslim religious tourism involves all travel forms practiced by Muslims either to fulfil a religious mandatory or recommended journey or to enhance their faith by visiting sites of religious value. Accordingly, religious tourism by Muslims includes two types of journeys:

\section{Hajj and Umrah}

Religious tourism is still an under-studied area due to the high sensitivity of the subject, the lack of scientific data and its domestic nature in most countries (El-Gohary, 2016).

Every Muslim is compelled to visit the holy city of Makkah (in the Kingdom of Saudi Arabia, KSA) to conduct Hajj if he/she is able to do. Hajj is a mandatory ritual that every adult, sane, able Muslim (physically and financially) has to perform once in life time. Hajj in Islam is performed in KSA within a specific geographical zone including the holy mosque in Makkah, Arafat, Muzdalifah, and Mina. It has to be completed in particular period, from the 8th to the 13th of the 12th month (Dhul-Hijja) according to the Hejri (Islamic) calendar and this explains why the season of Hajj is the peak of pilgrims' arrivals in Makkah.

Besides, millions of Muslims travel to the holy city of Makkah every year to perform Umrah. Umrah is also a pilgrimage to Makkah performed by Muslims; however it's not obligatory and can be performed at any time of the year. as Sunnah (actions done by Prophet Muhammed).

Although in Hajj and Umrah, Muslims use many facilities (transportation, accommodation, restaurants) just like tourists do, they actually consider these journeys as worship rituals in which they seek forgiveness from God. Muslims who travel for Hajj and Umrah don't consider themselves tourists rather pilgrims who are fulfilling a religious ritual that is highly rewarded by God. Therefore, many of the tourism organizations even UNWTO as well as many researchers exclude the number of Muslims who go to Hajj and Umrah from the total number of international tourists because of the distinct nature of these journeys. The National Statistical Office of Saudi Arabia, during 2014, announced that 21.66 million travellers visited KSA. The majority of these millions visited KSA for performing Hajj and Umrah;out of which 2,085,238 performed Hajj (El-Gohary, 2016).

\section{Ziyarat}

Ziyarat means visiting places associated with Prophet Muhammad, his family members and descendants, his companions, or other honored figures in Islam, as the Prophets, Shaikhs, and Islamic scholars (Scott and 
Jafari, 2011). Ziyarah also include mosques, graves, battlefields, mountains, and caves that are appreciated in Islamic history. The most important site for Ziyarat is Al Madinah Al Monawarah or the city of Prophet Muhamed in KSA. Almost all pilgrims who go for Hajj or Umrah visit Madinah to pray in the prophet's mosque and to stop over his tomb along with many other Islamic sites and battlefields.

Ziyarat is non-obligatory, however, more people engage in them every year. Unfortunately, there are no accurate records of Ziyarats. Ziyarat reflects the regional cultural expression of Islam, especially in the nonArab countries. Festivals associated with particular shrines may involve booths and entertainment activities that became attractive for even non-Muslim tourists (Scott and Jafari, 2011).

The Imam Reza's tomb and surrounding areas in Mashhad, Iran is the largest and holiest shrine of Iran which is visited by 12 to 15 million pilgrims every year. Provinces like Najaf and Karbala are another example for Ziyarat in Iraq that welcome Shiite pilgrims from many places like Iran and Pakistan (Scott and Jafari, 2011).

\section{Travel for non-religious purposes}

According to the study conducted by DinarStandard and Crescentrating in 2012, that excludes Muslims travel for religious purposes, the majority of Muslims travelled for leisure within the year 2011 constitute $(52.7 \%)$. Leisure tourism is the most popular among Arab tourists, where the main drive is entertainment and amusement. Muslim tourists especially Arabs, choose destinations that offer beach and water entertainment resorts or wilderness opportunities where they can enjoy with their families. Shopping, is perhaps the most favorable tourist activity among Arabs specially females while travelling (Abodeeb et. al, 2015). The rest of Muslims practice all other patterns of tourism such as business, attending conferences, adventure, sport, health and cultural tourism.

\section{Halal tourism}

\section{What does Halal mean?}

"Halal" is an Arabic word which means, "permissible" or allowed for Muslims and therefore refers to what is permitted and acceptable forms of behavior. Muslims around the globe share the core beliefs concerning Halal (permitted) and Haram (forbidden) even if their communities vary politically and culturally (Mohsin et al, 2016). Shari'ah (the Arabic word for Islamic law) provides Muslims with a comprehensive way of life that govern their daily life. It covers the worship duties as well as the social, economic, moral, even the political and military aspects of life. Shari'ah's decrees are derived from Quran and Sunnah (actions, sayings and consents of Prophet Muhammed). If there is a new situation that has no explicit decree in Quran and Sunnah, then Shari'ah adopts analogy (similarity of a new situation with an old one that has a clear decree) and consensus (agreement of Muslim scholars on completely new situations). Shari'ah determines what is Halal or permissible and what is Haram or impermissible for Muslims to do, say or consume.

\section{Halal tourism from the travellers prospective}

From the travellers prospective, Halal tourism refers to the need of Muslim travellers to adhere to their religious principles and to fulfil their faith duties when away from home. Religious beliefs affect Muslim adherences' attitudes and perceptions, and sometimes their choice of destination. Therefore, regardless of the type or the pattern of tourism practiced by the Muslim traveller, whether it is for a religious or a nonreligious purpose, as long as he/she is avoiding forbidden practices and products and as long as he / she is fulfilling his/her daily worship duties, he/she is practicing Halal tourism. However, Muslims vary among themselves in their adherence level to Islamic rules and in their religious commitment just like the followers of any other religion. This depends on individual's upbringing, religion background, culture and personality.

Hence, Halal tourism and religious tourism are totally different. Furthermore, Halal Tourism is not a subcategory of religious tourism as some researchers assume (El-Gohary, 2016). 


\section{Halal tourism from the destination prospective}

From the destination prospective, Halal tourism refers to the provision level of tourism products and services that satisfy the needs of Muslim travellers and that help them practice their ritual duties and dietary requirements in accordance with Islamic rules or Shari'ah (Mohsin et. al, 2016).

Numerous Muslim destinations have tried to appeal to this market segment of Halal tourism by offering superior hospitality services that facilitate a Muslim tourist to comply with Shari'ah laws. for example, the Federation of Islamic Associations of New Zealand announces lists of goods and services suppliers that help both residents and visitors to New Zealand to comply with their religious beliefs (Mohsin et al, 2016).

Another example is Australia's Gold Coast that offers Ramadan Lounge to attract Muslim tourists. In Thailand, the concept of Muslim-friendly was introduced to appeal to travellers from the Middle East. Global Health City, in Chennai, India, has become Halal certified to better serve its rising health tourists from Muslim countries. Even in Muslim majority destinations, hotels/resorts such as De Palma Group of Hotels in Malaysia, Al-Jawhara Hotel in Dubai, Amer Group of Resorts in Egypt, Ciragan Palace kempinski Hotel in Turkey are providing Muslim lifestyle allied amenities (Dinar Standard and Crescentrating, 2012).

Definitely, in the KSA, as the Hajj destination, all hotels and other services' organizations have the exact requirements of Muslim travellers. For example, all recreational facilities for men and women are separated and all restaurants are serving Halal food only (Shafaei, 2015).

\section{Faith-based needs of Muslim Travellers}

The human well-being is the heart of all Islamic decrees. This necessitates a balanced satisfaction of both the spiritual and physical needs of individuals. In the Islamic faith, religion is an integral part of its adherents' daily life and its rules guide all their life activities and practices (Scott and Jafari, 2011).

Arab/Muslim tourists often travel to countries like Malaysia, Indonesia, Singapore, United Arab Emirates and Turkey where they can worship freely. The availability of Muslim-oriented facilities and services that cater for Muslim travellers' ritual needs is the key factor that strictly influences Muslims' decisions for a destination, a hotel, food consumption and activities while travelling. Tourism destinations that wish to successfully target Muslim travellers must provide services and products that fulfill their faith based needs (Stephenson, 2014; Mohsin et al., 2016; Nassar et al.,2015; Abodeeb et al., 2015; Zamani-Farahani and Musa 2012, Eid and El-Gohary, 2014).

A recent study by MasterCard andCrescentRating in 2016 tried to identify the special needs of Muslim travellers based on their religion. It has classified these needs into six main areas. These needs apply to all Muslim travellers according to Islamic Shari'ah. However, as mentioned earlier, the level of adherence to the faith-based needs varies among Muslims. These areas are:

\section{Halal Food}

Halal food is by far the most critical requirement that a Muslim traveller seeks when traveling. Islamic Shari'ah identifies the permissible food to be consumed. For example, pork and alcohol are prohibited in Islam. Besides, Muslims are to eat Halal meat, of an animals, slaughtered according to Islamic specifications. The Halal concept involves the entire food chain from the origin to the processing of food. Besides, tools and devices used must be cleansed in accordance with Islamic Shari'ah and not to get contaminated by contact with impermissible constituents (Henderson, 2016).

On a survey done by Dinar Standard and Crescentrating, LLC in 2012 about the essentials for Muslim tourists while travelling, the top answers given were, "Halal Food" $(67 \%)$, followed by "Overall price" (53\%), and "Muslim-friendly experience" (49\%). "Halal food option" was mentioned as one of the top requirements when asked about the necessities they look for when deciding on the hotel accommodation or the airline. For non-Muslim majority, "Halal" food options stand out as the top attribute (Dinar Standard and 
Crescentrating, 2012). so of a number of authors have advised hotels and restaurants how to become Halal food certified to help cater for the Muslim travellers (Jafari and Scott 2014; Stephenson , 2014; Eid and ElGohary 2015; Henderson 2016).

Many studies actually stressed the importance of Halal food options for Muslim tourists while travelling. Surveys which have been conducted revealed that it is an urgency and often concern for Muslims while travelling (Stephenson, 2014; Mohsin et al., 2016; Henderson, 2016). Furthermore, Halal food is sometimes desired by non-Muslims who prefer Halal options as natural and healthier (Gabdrakhmanov et al., 2016). Hence, restaurants and hotels in the tourism destinations that desire to attract these segments have to acquire knowledge about Halal food and provide accordingly. Countries such as Indonesia, Malaysia, Turkey and the UAE are perfectly accommodating both Muslims and non-Muslims as per food requirements (Henderson, 2016).

\section{Prayer Facilities}

Prayer is the second of the five pillars of Islam and the only one that is required to be performed daily. It is a fundamental element of Islamic practice and worship. It's impermissible for any Muslim under any circumstances to neglect his/her daily prayers. While traveling, it's allowed for Muslims to shorten and combine some prayers and perform them three times a day instead of five.

In order to satisfy this need, tourism services and facilities such as shopping malls and airports have to provide Muslim travellers with separate prayer rooms for men and women. Hotels can either provide prayer rooms or provide prayer mats and the indication for the direction of Makkah (Qibla) in guest rooms, as Muslims have to face Makkah while praying. Prayer rooms should be provided with ablution or Wudhu area equipped with "foot washing" facilities. Wudhu is the washing ritual performed by Muslims before their prayers.

\section{Water-usage Friendly Washrooms}

Body cleanliness is a vital aspect in Islam. Therefore, water plays a focal role in hygiene for Muslims. Hence, special care is given to hygiene in the washroom. Muslim travellers feel completely uncomfortable if the water use is not accessible in toilets. Providing such facilities has become more acquainted now with the prevalent availability of hand showers, bidets or even Japanese-style toilets. The hand shower is a plumbing fixture located in a holder against a wall next to the toilet. Hand showers are very common in Muslim countries as well as South and Southeast Asian countries (MasterCard andCrescentRating, 2016). However, this facility is still uncommon in Europe.

\section{Ramadan Services}

Ramadan is a holy month for Muslims. In Ramadan, food and liquids are forfeited in daylight hours. Although Muslims don't prefer to travel amid the time of Ramadhan, many of them do if this period involves school vacations. Destinations hoping to pull in Muslim tourists during this period should have the capacity to provide their exceptional needs while fasting. Hotels and restaurants for example need to provide predawn and sun-sit Halal meals during this month (MasterCard andCrescentRating, 2016; Stephenson, 2014).

Some actions and practices are considered 'Haram' or non-Halal (impermissible in Islam). Muslims while travelling require a family-friendly environment and prefer to avoid places that serve alcohol, have nightclubs or a gambling facility (MasterCard andCrescentRating, 2016).

\section{Leisure Facilities with Privacy}

Many Muslim travellers prefer separate leisure facilities that assure privacy for males, females and families. These include separate swimming pools, gyms and beaches with the Islamic dress code (MasterCard and CrescentRating, 2016; Gabdrakhmanov et. al, 2016). 


\section{Conservative entertainment}

Other attributes that concern Muslims while travelling that were highlighted in researches are the conservative entertainment such as conformist television channels, no seductive music, non-figurative patterns of decoration (Stephenson, 2014), and Islamic dress codes for employees (Zamani-Farahani and Henderson, 2010).

Hoteliers around the world realized the importance of Halal tourism as a promising market segment and started to provide Muslim travellers' requirements. In August 2011, Tourism Queensland, Australia, posted a new advertisement called "Marhaba! Welcome to Australia's Gold Coast". Their campaign directly targeted the Middle East Arab Muslims by focusing on some of Muslims' practices in the holy month of Ramadan that fell in August of that year, and stressed such attributes as Halal restaurants (Abodeeb et al., 2015).

\section{Top Muslim Tourist Destination Countries}

Based on the number of visits, the top destinations for Muslim tourists are Malaysia, Turkey, and UAE. The following six markets are Singapore, Russia, China, France, Thailand and Italy. This evaluation is based on data originated from top Muslim generating markets that represent $73 \%$ of total expenditure (Dinar Standard and Crescentrating, LLC, 2012). It's very clear that Muslim tourists prefer OIC destinations that have a definite advantage of Muslim facilities, products and services. In 2014 Malaysia and Turkey attracted 13\% of total Muslim travellers. (MasterCard - CrescenRating Global Muslim Traveller Index 2015).

\section{Case1. Malaysia}

As far back as the September 11 incident, Malaysia became a very popular destination for Muslim travellers (Samori et al., 2016). As more restrictions are imposed on Muslim visitors in the West, they switched their travel direction toward the East. In 2012, 5.44 million Muslim tourists visited Malaysia. They represented around $21 \%$ of total tourists' arrival in Malaysia at that year. As per the Islamic Tourism Center, Malaysia is number one destination for Muslim travellers for four consecutive years since 2011 (Islamic Tourism Center, 2015).

Malaysian government has been very active in promoting Malaysia to Muslim travellers specially from the Middle East (ME) and this caused the steady growth in Islamic tourism market to Malaysia since 2001. The ME tourists segment exemplifies an important part of the Malaysian tourism industry. For example, as per UNWTO estimations, each ME tourist spends RM7000 in each visit to Malaysia, while tourists from other origins spend an average of RM2300 only (Risi, 2012). Malaysian government did a lot to comfort and welcome the ME Muslim tourists. For instance, it has introduced 'Feel-at-Home' campaign such as "Ain Arabia", the street that depicts Middle Eastern cultures and cuisine, developed the signage in Arabic language, provided multi- language menu at the restaurants and brochures for tourist information, and has employed many Arab-speaking staff at hotels, tour agents and shopping complexes (Shafaei \& Mohamed, 2015).

On a greater perspective, Malaysia took very good care of offering essential Islamic values in most of the tourism products and services. Halal food for example is available almost everywhere in Malaysia. Halal food is one fundamental element for Muslim travellers. Hence, in 2010, Malaysian government has encouraged hotels and restaurants to obtain Halal certificate to please Muslim tourists . Since $60 \%$ of Malaysian population is Muslim, providing Halal food was not a hard encounter for Malaysia. Tourists can find Halal food available at both street kiosks and fine dine restaurants. Friendly Muslim population is another important factor that attract Muslim tourists to Malaysia (Shafaei \& Mohamed, 2015).

Regarding accommodation, Malaysia is known to be a non-conservative Islamic country, however it has started to offer a wide range of Islamic accommodation to satisfy Muslim tourists. In Malaysia, there are three categories of Muslim friendly hotels (Md Salleh, 2014). Table( 1) show the ranks of Muslim friendly hotels available in Malaysia. 
(Table 1) Categories of Muslim friendly hotels in Malaysia.

\begin{tabular}{|c|c|}
\hline Type & Type of Islamic services \\
\hline Basic & $\begin{array}{c}\text { Halal food, no alcohol, Qiblah signage, prayer } \\
\text { mat, bidet in the room }\end{array}$ \\
\hline Intermediate & $\begin{array}{c}\text { Separate recreation facilities for male and female, } \\
\text { Musollah, no adult entertainment, prayer time, } \\
\text { Mosque location. }\end{array}$ \\
\hline Extensive & $\begin{array}{r}\text { Zakat counter, Islamic related brochure, classes, } \\
\text { Azan at the floor level }\end{array}$ \\
\hline
\end{tabular}

Source: (Md. Salleh, 2014).

Considering shopping malls, the government of Malaysia has required all the shopping malls to provide prayer rooms, ablution facilities and Halal restaurants to enhance the shopping experience for Muslim tourists. (Islamic Tourism Centre, 2015). The main shopping centres at Kuala Lumpur have signage in Arabic language for the ease of ME tourists.

As Halal tourism is a booming travel segment, Malaysian tourism industry is trying hard to improve the Islamic tourism related facilities and to provide high quality tourism services at hotels, restaurants and attractions and shopping centres to ensure repeat visits and to support the positive image of Malaysia among Muslim tourists.

\section{Case 2, Turkey}

Turkey is ranked among the top favoured destinations for Halal tourism. UNWTO in 2008 declared that the three Muslim countries of Turkey, Malaysia and Egypt had the highest numbers of inbound tourists because of their appeal to non-Muslim holidaymakers. According to the Muslim Traveller Index Europe for 2014, the size of the global Halal tourism market is estimated to be TK 300 billion. Global Muslim Travel Index ranked Turkey as the second top destination for Halal tourism from 2012 till 2015. In 2016, Turkey came third after UAE (MasterCard - CrescenRating Global Muslim Traveller Index, 2016). Turkey has also arisen as one of the top European destinations (5th on the list) for Halal tourism attracting Muslims from the Middle and Far East. According to the Muslim Travel Index Europe 2014, 58\% of tourists were attracted to visit Turkey because of to its rich Islamic heritage, $97 \%$ of the investigate respondents, proposed the availability of Halal food in Turkey to be 'important' while $89 \%$ specified prayer facilities to be 'important' (Mohsin, 2016).

There are two agencies overseeing the Halal certification and accreditation of services in Turkey. These agencies are - KAS DLUSLARARASI Sertifikasyon GÖZ Ve TEK KON. Hiz LTD Sti (KASCERT) and Association for the Inspection and Certification of Food and Supplies (GIMDES). Approximately 70 hotels in Turkey are deliberately advertising themselves with keywords such as 'Islamic hotel', 'conservative vacation' and 'Halal Tourism' to attract Muslim tourists. The province of Yalova and the beach resort town of Alanya have nine hotels that comply with Shari'a laws (Mohsin et al., 2016). Beside providing Halal food and prayer facilities, some hotels in Turkey offer separate swimming pool and leisure facilities for men and women (Eid \& El-Gohary,2015).

The hospitality industry is a major supplier in the tourism industry and its success in complying with the requirements of Muslim tourists will definitely mean the success of Halal tourism in this destination. To enhance their image in the market and to increase their market share in Halal tourism, hoteliers in Turkey also seek Halal certification to assures Muslim tourists that the hotel delivers the necessary amenities they 
need (Mohsin et al.,2016).

Muslim tourists perceive Turkey, being a Muslim state in Europe, to be more welcoming than other European nations after the incident of 11th of September 2001. For example, the first nine months of 2002 witnessed 50\% more arrivals at 44,819 from the Gulf than in 2001, with Saudi arrivals within this totalling 23,420 . Turkey is well connected to Gulf countries by air; visa services are also available in all gulf countries. There is much for Muslim families to see and do in Turkey. They can enjoy beach / seaside holidays, adventure tourism in the mountains, sightseeing tours in Istanbul and Ankara for architectural monuments, the wide range in cuisine on offer, and shopping for old-style carpets and other handicraft items (WTO, 2003).

Lastly, there was a great shift of Muslim tourists demand specially from the Gulf area and the middle east in the wake of 11 September 2001 towards Islam destinations. It is understandable that Muslim destinations are more safe and comfortable for Muslim tourists. Turkey as an Islamic nation in Europe can definitely benefit a lot from this shift by offering the Muslim tourist specially the Middle Eastern one the best of both worlds.

\section{Conclusion and Recommendations:}

From the above text it could be concluded that tourism is an endorsed practice in Islam for many lawful proposes. While travelling, Muslims need to adhere to certain limitations and avoid impermissible actions and products as per Islamic Law. Halal tourism perception is much broader than Religious tourism. 'Religious Tourism' indicates visiting holy places of Islam and sites of historical and religious values. Halal tourism is a comprehensive perception in which Muslims can travel for entertainment or adventure or any other purpose while seeking Halal food and pursuing their ritual duties.

Halal tourism is definitely one of the most rapidly growing segments that reflect high economic potentials for tourist destinations not only for Muslim majority destinations but also for non- Muslim ones. To attract Muslim tourists, especially from the Middle East markets, the following recommendations are suggested for tourism bodies and suppliers:

- Destination Management Organizations (DMOs), especially in Western countries, need to add some Muslim relevant services to their websites, such as prayer times, locations of mosques and halal food restaurants. DMOs need to consider and comprehend Muslim beliefs when choosing visual images and text for their promotional campaigns.

- Hoteliers may need to observe a conservative dress code for their female staff and prevent free mixing in entertainment areas. Tourism suppliers may also have to instruct their staff on proper cross-cultural communication, to be able to serve Muslim tourists. It is also recommended that tourism suppliers and authorities become more aware of the distinguished attitudes and behaviors of Muslim tourists.

- Tourism and Hotel bodies can promote Islamic events and festivals to attract Muslim tourists. For example; the Gold Coast in Australia offers a Gold Coast Ramadan Lounge to appeal to Muslim tourists. In Thailand, spa-outlets have developed the concept of Muslim-friendly spas to attract tourists from the Middle east. Global Health City, in Chennai, India, has become Halal certified to better satisfy its growing segment of tourists from Muslim countries coming for health purposes. Even in destinations with Muslim inhabitants' majority, hotels/resorts such as De Palma Group of Hotels in Malaysia, Al-Jawhara Hotel in Dubai, Amer Group of Resorts in Egypt, Ciragan Palace kempinski Hotel in Turkey offer Muslim lifestyle related services, i.e. not serving alcohol, appointing separate timings for women in leisure services, offering prayer facilities and more. Airlines are not excluded from this and have to start to pay attention to Muslim travellers' needs especially dietary.

- There is a need for a global standardized understanding of Halal tourism and its required services and of national and international organizations that can accredit tourism Hotels as being Halal. 
Islamic establishments in Muslim and non- Muslim countries should play an effective role in advising tourism and hospitality firms how to become Halal friendly. Halal tourism requires rebranding and reforming the hospitality industry to satisfy Muslim tourists' needs. In Muslim destinations, hotels can create their own brand image by promoting Halal tourism services and facilities. Also any hotel in a non-Muslim destination can also apply Halal tourism strategy to attract Muslim tourists.

The great number of Muslims and the fast spread of Islam will help Halal Tourism requirements to gain a wider international acceptance. Many hotels around the world recognized the financial importance of this segment and implemented Muslim friendly settings.

\section{Bibliography:}

1. Abodeeb, J.; Wilson, E. and Moyle, B. (2015). Shaping destination image and identity: Insights for Arab tourism at the gold coast, Australia. International Journal of Culture, Tourism and Hospitality Research, 9(1), 6-21.

2. Dinar Standard and Crescentrating, L.L.C. (2012). Global Muslim lifestyle travel market- landscape and consumer needs study-executive summary, Retrieved October 18, 2016 from: http://advisory.dinarstandard.com/travelstudy/\#top.

3. Eid, R. and El-Gohary, H. (2015). Muslim Tourist Perceived Value in the Hospitality and Tourism Industry, Journal of Travel Research, 54(6) 774-787

4. El-Gohary,H. ( 2016). Halal tourism, is it really Halal?, Tourism Management prospectives, 19, 124-130.

5. Gabdrakhmanov, N.K.; Biktimirov, N.M., Rozhko, M.V. and Mardanshina, R.M. (2016). Features of Islamic Tourism, Academy of Marketing Studies Journal, 20 (1), 45-50.

6. Henderson, J. C. (2016). Halal food, certification and halal tourism: Insights from Malaysia and Singapore, Tourism Management Perspectives, 19, 160-164.

7. Islamic Tourism Centre (2015). Grab a bigger slice of Muslim market. Retrieved 24 May 2016, from http://itc.gov.my/itc-news/grab-a-bigger-slice-of-muslim-tourism- market/.

8. Jafari, J., and Scott, N. (2014). Muslim world and its tourisms. Annals of Tourism Research, 44, 119.

9. MasterCard and CrescenRating (2015), MasterCard - CrescenRating Global Muslim Traveller Index 2015, Retrieved November 2, 2016 from: http://www.cresentrating.com.

10. MasterCard and CrescentRating (2016). MasterCard-CrescentRating Global Muslim Travel Index 2016, Retrieved February 18,2017 from: http://www.cresentrating.com.

11. Md Salleh, N. Z. (2014). Establishing the Shariah-compliance hotel from the Muslim needs perspective. Theory and practice in hospitality and tourism research. Croydon, United Kigndom: CRC Press Taylor \& Francis.

12. Mohsin, A.; Ramli, N. and Alkhulayfi, B. A. (2016), Halal tourism: Emerging opportunities, Tourism Management Perspectives, 19, 137-143.

13. Nassar, M. A. ; Mostafa, M.M, and Reisinger ,Y., (2015). Factors influencing travel to Islamic destinations: an empirical analysis of Kuwaiti nationals, International Journal of Culture, Tourism and Hospitality Research, 9(1), 36 - 53.

14. Pew Resource Center (2011). The future of the global Muslim population. Retrieved October 14, 2016 from: www.pewforum.org/2011/01/27/the-future-of-the-global-muslim-population.

15. Rise, M. (2012). International tourism receipts surpass US\$ 1 trillion in 2011. UNWTO world tourism barometer.

16. Samori, Z., Md Salleh, N.Z. and Khalid, M.M, (2016), Current trends on Halal tourism: Cases on selected Asian countries, Tourism Management Perspectives 19, 131-136. 
17. Scott, N., and Jafari, J.(2011). This is a chapter. In UNWTO, Religious Tourism in Asia and the Pacific (pp, 47-58). Madrid: UNWTO.

18. Shafaei, F. and Mohamed, B., (2015). Involvement and brand equity: a conceptual model for Muslim tourists, International Journal of Culture, Tourism and Hospitality Research, 9(1), 54 -67.

19. Shafaei, F., and Mohamed, B. (2015). Malaysia's branding as an Islamic tourism hub: An assessment. GEOGRAFIA Online Malaysia Journal of Society and Space, 11(1), 97-106.

20. Stephenson, M. L. (2014), Deciphering 'Islamic hospitality': Developments, challenges and opportunities, Tourism Management, 40, 155-164.

21. Thomson Reuters and Dinar Standard (2013). State of the global Islamic economy report, Retrieved February 15, 2017 from: http://www.dinarstandard.com/travel-sgie-report-2013/

22. UNWTO (2003), Outbound Tourism from Saudi Arabia, Madrid, Spain.

23. UNWTO (2008), Facts and figures. Tourism 2020 Vision. Retrieved December 23, 2016 from http://www. unwto.org/facts/menu.html.

24. Zamani-Farahani H. and Henderson J. C. (2010). Islamic Tourism and Managing Tourism Development in Islamic Societies: The Cases of Iran and Saudi Arabia, International Journal of Tourism Research, 12 (1): 79-89.

25. Zamani-Farahani H. and Musa, G. (2012). The Relationship between Islamic Religiosity and Residents' Perceptions of Socio-cultural Impacts of Tourism in Iran: Case Studies of Sare'in and Masooleh, Journal of Tourism Management, 33 (4): 802-14.

\section{هل الإسلام مع أم ضد ممارسة السياحة؟ السياحة الحلال: المفهوم والمتطلبات.}

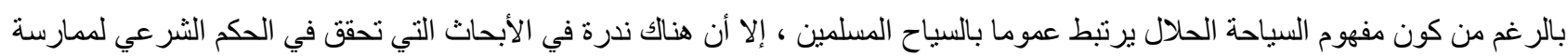

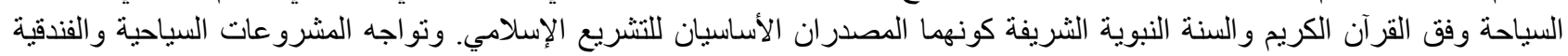

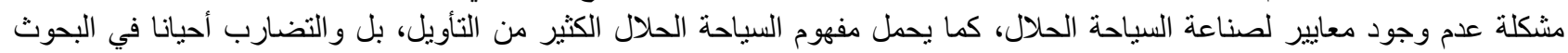

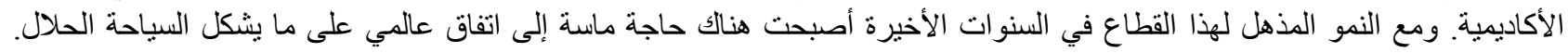

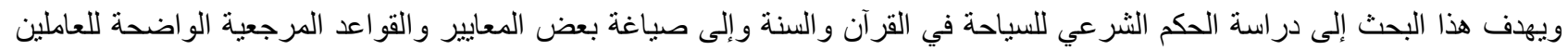
بمجال السياحة الحلال، وتنتهي الورقة بعدد من التوصيات للمستثمرين في هذا القطاع.

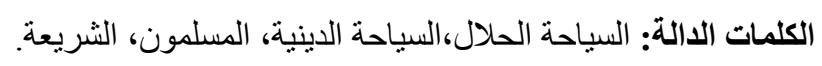

